dr inż. Zygmunt Marciniak, prof. IPS

mgr inz. Wojciech Jakuszko

mgr inz. Piotr Michalak

Instytut Pojazdów Szynowych ,TABOR”

\title{
Nowe układy i rozwiązania techniczne w modernizowanej lokomotywie spalinowej serii SM42 typu 6Di
}

\begin{abstract}
Lokomotywy spalinowe serii SM42 byty produkowane przez Fabryke Lokomotyw w Chrzanowie przez ponad 30 lat. Ogółem wyprodukowano około 1800 lokomotyw. W latach 70-tych część lokomotyw wyposażono $w$ instalacje ogrzewania wagonów, a w latach 1999-2000 40 sztuk lokomotyw wyposażono $w$ agregat pradotwórczy $i$ trójfazowa pradnice synchronizowana do ogrzewania wagonów. Lokomotywy serii SM42 należa do najpopularniejszych lokomotyw spalinowych eksploatowanych $w$ Polsce. Próby modernizacyjne lokomotyw rozpoczęto w polowie lat 90-tych. W ostatnich latach Newag Nowy Sacz oraz Pesa Bydgoszcz podjęty się kompleksowej modernizacji lokomotyw serii SM42 dla potrzeb PKP Cargo SA oraz zakładów przemystowych $w$ oparciu o silnik CAT C27 i C15 firmy Catterpillar.

Prezentowany artykut jest poświęcony trzeciemu wariantowi modernizacji, realizowanemu wspólnie przez Instytut Pojazdów Szynowych „TABOR” w Poznaniu i Fablok Chrzanów, w oparciu o silnik spalinowy firmy MAN.

$W$ artykule zaprezentowano charakterystyki trakcyjne i możliwości pociagowe lokomotywy oraz jej podstawowe parametry. Ponadto przedstawiono opisy nowych $i$ zmodernizowanych zespołów $i$ układów oraz zakres prób $i$ badań będacych do wykonania dla uzyskania świadectwa dopuszczenia do eksploatacji. Referat powstat $w$ ramach realizowanego projektu celowego $\mathrm{nr}$ 6ZR6 2008C/07089 pt. Zmodernizowana lokomotywa manewrowa typu 6D (serii SM42) z silnikiem spalinowym spetniajacym wymagania normy EURO IIIa.
\end{abstract}

\section{Wprowadzenie}

Lokomotywy spalinowe serii SM42 (6D) zaprojektowane w CBK PTK w Poznaniu w połowie lat pięćdziesiątych były produkowane przez Fabrykę Lokomotyw w Chrzanowie przez ponad 30 lat.

Ogółem wyprodukowano około 2000 sztuk tych najbardziej popularnych lokomotyw z czego około 1200 na potrzeby Polskich Kolei Państwowych, 600 sztuk dla zakładów przemysłowych a 37 sztuk wyeksportowano do Maroka. Lokomotywy przeznaczone były do prowadzenia prac manewrowych i pracy liniowej z pociagami towarowymi i wyposażone były w wózki typu $6 \mathrm{D}, 1 \mathrm{LN}$ i $1 \mathrm{LNa}$.

W latach 1975-1977 około 40 lokomotyw zostało przystosowanych do ogrzewania wagonów osobowych. Przebudowa lokomotyw (oznaczonych SU42) polegała na wyposażeniu ich $\mathrm{w}$ instalację elektryczną o napięciu $500 \mathrm{~V}$ zasilaną z prądnicy głównej. Wymagało to wykonania dodatkowego okablowania i montażu sprzęgów grzewczych.
W latach 1999-2000 lokomotywy serii SP42 przeznaczone do prowadzenia pociągów pasażerskich (wyposażonych wcześniej w kocioł grzewczy typu WB-5 do wytwarzania pary) zostały przystosowane do ogrzewania elektrycznego wagonów osobowych. W miejsce kotła typu WB-5 zabudowany został agregat prądotwórczy składający się z silnika spalinowego typu CAT 3208 o mocy $180 \mathrm{~kW}$, synchronicznej prądnicy trójfazowej i układu prostownikowego, dostarczającego prąd o napiciu 3000V. Ogółem przebudowano 40 lokomotyw.

Lokomotywy serii SM42 nie były kompleksowo modernizowane przez ponad 40 lat.

Dopiero w 1996r. Zakłady Naprawcze Taboru Kolejowego w Pile wspólnie z Ośrodkiem Badawczo - Rozwojowym Pojazdów Szynowych (obecnie IPS „Tabor”) w Poznaniu została wykonana pierwsza modernizacja lokomotywy SM42, którą oznaczono SM42-2000 (6Dc). 
Lokomotywa została wyposażona w silnik typu 12V396TC12 produkcji Faur (Rumunia) na licencji MTU, elektroniczny regulator, prądnicę główną prądu przemiennego i sprężarkę śrubową oraz tablicę pneumatyczną (pierwszą zainstalowaną w krajowych pojazdach trakcyjnych zaprojektowaną w OBRPS Poznań). Ponadto, dla poprawy warunków pracy maszynistów lokomotywa została wyposażona w zmodernizowaną kabinę sterowniczą (oparta na amortyzatorach) z dwoma pulpitami sterowniczymi i drzwiami wejściowymi z bocznych pomostów, smarowaniem obrzeży kół oraz halogenowym oświetleniem zewnętrznym.

Ogółem wyprodukowano tylko jedną lokomotywę przystosowaną do sterowania radialnego eksploatowaną obecnie przez PKP Cargo SA.

W latach 1997-1999 w przedsiębiorstwie Taboru Kolejowego i Gospodarki Kamieniem w Rybniku dokonano również modernizacji lokomotywy SM42 (oznaczonej LS1000 - 6Dd dla kopalni węgla kamiennego) w oparciu o silnik wysokoprężny typu 8V396TC14 o mocy 785kW firmy MTU i synchroniczną prądnicę główną typu LSG 850 - 90 wraz ze wzbudnica, prądnicą pomocniczą i zespołem prostownikowym produkcji ABB Dolmel Drives. Ponadto w lokomotywie zabudowano nowy agregat chłodniczy silnika spalinowego, sprężarkę śrubową $\mathrm{i}$ oświetlenie halogenowe. Lokomotywa wyposażona została także w nowoczesną kabinę sterowniczą odizolowaną od podwozia, dwa pulpity sterownicze i nowoczesne fotele oraz nowoczesne układy sterowania i diagnostyki.

Ogółem wyprodukowano 2 sztuki lokomotyw które powstały dopiero na początku 2002r.

Przez następne kilka lat nie było zainteresowania modernizacją lokomotyw serii SM42.

Dopiero w 2007r. powstała prototypowa lokomotywa serii SM42 (6Dg) zmodernizowana przez Newag Nowy Sącz, a kilka lat później w Pesa Bydgoszcz wyprodukowano zmodernizowaną lokomotywę typu $6 \mathrm{Dk}$ z dwoma zespołami prądotwórczymi.

W lokomotywie 6Dg zastosowano zespół prądotwórczy w oparciu o silnik CAT C27 o mocy $652 \mathrm{~kW}$, a w lokomotywie 6Dk dwa silniki CAT 15 o mocy $403 \mathrm{~kW}$ każdy $[2,3]$.

Pozostałe modernizacje (różnice w zastosowanych różnych aparatach i urządzeniach) dotyczyła dla obu typów lokomotyw (6Dg i 6Dk) zespołu prądnic synchronicznych, kabin sterowniczych i pulpitów, mikroprocesorowych układów diagnostyki i sterowania, wprowadzenie napędów asynchronicznych dla napędu sprężarek i wentylatorów, silników trakcyjnych (w lokomotywie 6Dk zastosowany napęd hydrailiczny), zabudowy systemu gaśniczego, elektronicznych prędkościomierzy i urządzeń do pomiaru paliwa, urządzeń smarowania obrzeży kół i układu hamulca (wprowadzono tablice pneumatyczne, mani- pulatory pulpitowe, hamulec postojowy typu sprężynowego) oraz oświetlenia zewnętrznego i sygnalizacji.

Oba typy lokomotyw eksploatowane są głównie przez PKP Cargo SA, przy czym 3 sztuki lokomotyw typu 6Dg produkcji Newag Nowy Sącz wykorzystywane są w ISD Huta Częstochowa Sp z o. o. [2,3]

Podobna $\mathrm{w}$ zakresie modernizacji powstaje lokomotywa SM42 (typ 6Di) przygotowywana w Pierwszej Fabryce Lokomotyw Spalinowych w Polsce - Fablok Chrzanów wspólnie z Instytutem Pojazdów Szynowych „Tabor” w Poznaniu. Lokomotywa przygotowywana jest $\mathrm{w}$ oparciu o silnik spalinowy firmy MAN oraz krajowy zespół prądnic. [1]

Widok ogólny modernizowanych lokomotyw serii SM42 wykonanych przez Newag Nowy Sącz i Pesa Bydgoszcz przedstawiono na rys 1 i 2 a porównanie parametrów wszystkich trzech lokomotyw zaprezentowano w tablicy 1 .

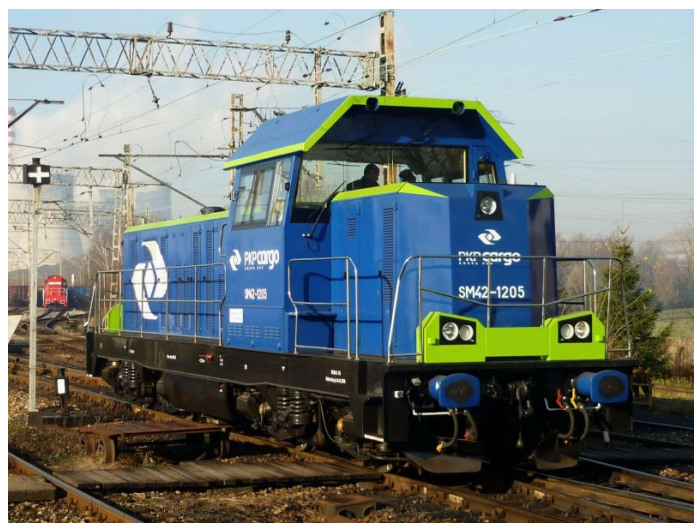

Rys.1 Widok zmodernizowanej lokomotywy SM42 (6Dg) wykonanej przez Newag Nowy Sącz

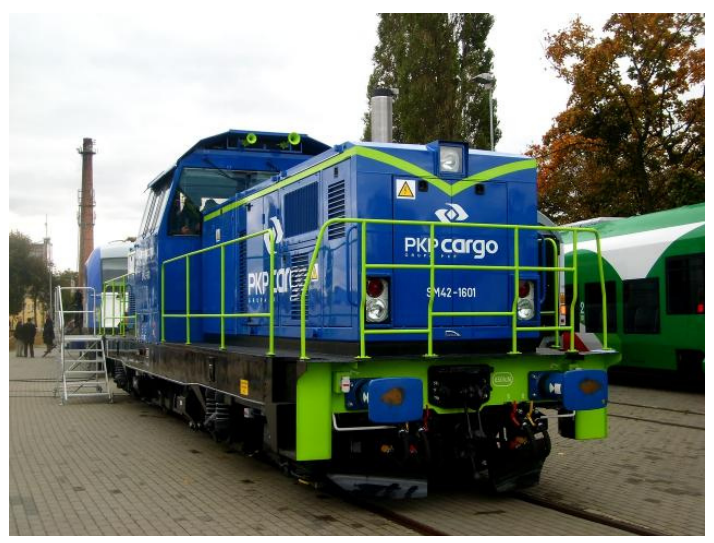

Rys.2 Widok zmodernizowanej lokomotywy SM42 (6Dk) wykonanej przez Pesa Bydgoszcz

\section{Charakterystyka trakcyjna i parametry lo- komotywy SM42 (6Di)}

Zmodernizowana lokomotywa spalinowa serii SM42 typu 6Di będzie przeznaczona do prowadzenia ciężkich prac manewrowych oraz lekkich pociagów towarowych z prędkością do $90 \mathrm{~km} / \mathrm{h}$.

Zasadniczo (ze względu na ograniczony zakres modernizacji i niskie jej koszty) lokomotywa będzie 
Parametry techniczne lokomotyw spalinowych serii SM42 zmodernizowanych w ostatnich latach. Tablica 1

\begin{tabular}{|c|c|c|c|c|c|}
\hline \multirow{2}{*}{ L.p. } & \multirow{2}{*}{$\begin{array}{l}\text { Wielkość lub } \\
\text { parametr }\end{array}$} & \multirow{2}{*}{ Jednostka } & \multicolumn{3}{|c|}{ Typ lokomotywy / Producent } \\
\hline & & & 6Dg/Newag & $6 \mathrm{Dk} /$ Pesa & 6Di/Fablok \\
\hline 1 & Układ osi & - & Bo-Bo & Bo-Bo & Bo-Bo \\
\hline 2 & Szerokość toru & $\mathrm{mm}$ & 1435 & 1435 & 1435 \\
\hline 3 & Moc znamionowa & $\mathrm{kW}$ & 652 & $2 \times 403$ & 662 \\
\hline 4 & Prędkość max. & $\mathrm{km} / \mathrm{h}$ & 85 & 90 & 90 \\
\hline 5 & Siła pociagowa max. & $\mathrm{kN}$ & 219 & 279,6 & 240 \\
\hline 6 & Masa lokomotywy & $\mathrm{Mg}$ & $70 \pm 3 \%$ & 70 & 74 \\
\hline 7 & Typ silnika spalinowego & - & $\mathrm{C} 27$ & $2 \mathrm{xC} 15$ & D2842LG622 \\
\hline 8 & Typ prądnicy głównej & - & $\begin{array}{c}\text { Siemens } \\
\text { 1FC454-4809SZ }\end{array}$ & $\begin{array}{l}\text { 2xSiemens } \\
1 \mathrm{FC} 2401\end{array}$ & Ghp400M4C, 59 \\
\hline 9 & Typ prądnicy pomocniczej & - & $\begin{array}{c}\text { Siemens } \\
\text { 1FC2282-6BO992 }\end{array}$ & $\begin{array}{l}\text { Prądu przemiennego } \\
\text { z napędem hydrost. }\end{array}$ & Ghp315S4R63 \\
\hline 10 & Typ silnika trakcyjnego & - & $\mathrm{LSa} 430$ & LSa430 & LSa430 \\
\hline 11 & Rodzaj przekładni & - & $\mathrm{AC} / \mathrm{DC}$ & $\mathrm{AC} / \mathrm{DC}$ & $\mathrm{AC} / \mathrm{DC}$ \\
\hline 12 & System hamulca & - & Oerlikon & Oerlikon & Oerlikon \\
\hline 13 & System sterowania & - & mikroprocesorowy & mikroprocesorowy & mikroprocesorowy \\
\hline
\end{tabular}

oferowana zakładom przemysłowym, dla zmniejszenia kosztów eksploatacji w wyniku zastosowania silnika spalinowego o mniejszym zużyciu oleju napędowego i środków smarnych, wydłużonymi przebiegami do poszczególnych poziomów utrzymania, zabudowy nowoczesnych podzespołów i aparatów o niskich kosztach utrzymania oraz nowoczesnej kabiny sterowniczej poprawiającej warunki pracy, obsługi i komfortu cieplnego i akustycznego [1].

Widok ogólny modelu zmodernizowanej lokomotywy typu 6Di przedstawiono na rys.3 a jej charakterystykę trakcyjną na rys.4.

\section{Ogólny opis nowych i zmodernizowanych urządzeń, zespołów i układów.}

W modernizowanej lokomotywie jest przewidziana budowa modułowa tzn. każdy z głównych jej układów zostanie umieszczony $\mathrm{w}$ modułach (sekcjach samonośnych), z możliwością ich podnoszenia za pośrednictwem suwnicy dla realizacji prac montażowych, przeglądowych i naprawczych. Moduły lokomotywy będą połączone $\mathrm{z}$ ostoją (niezmodernizowaną w ogólnym kształcie) gwarantując pewną szczelność.

Widok ogólny rozmieszczenia maszyn i urządzeń $\mathrm{w}$ zmodernizowanej lokomotywie przedstawiono na rys.5, a ogólne zestawienie głównych modułów ostoi, układów i zespołów elektrycznych, pneumatycznego, zespołu prądotwórczego, kabiny sterowniczej i sprężarkowo - wentylacyjnego na rys.6.
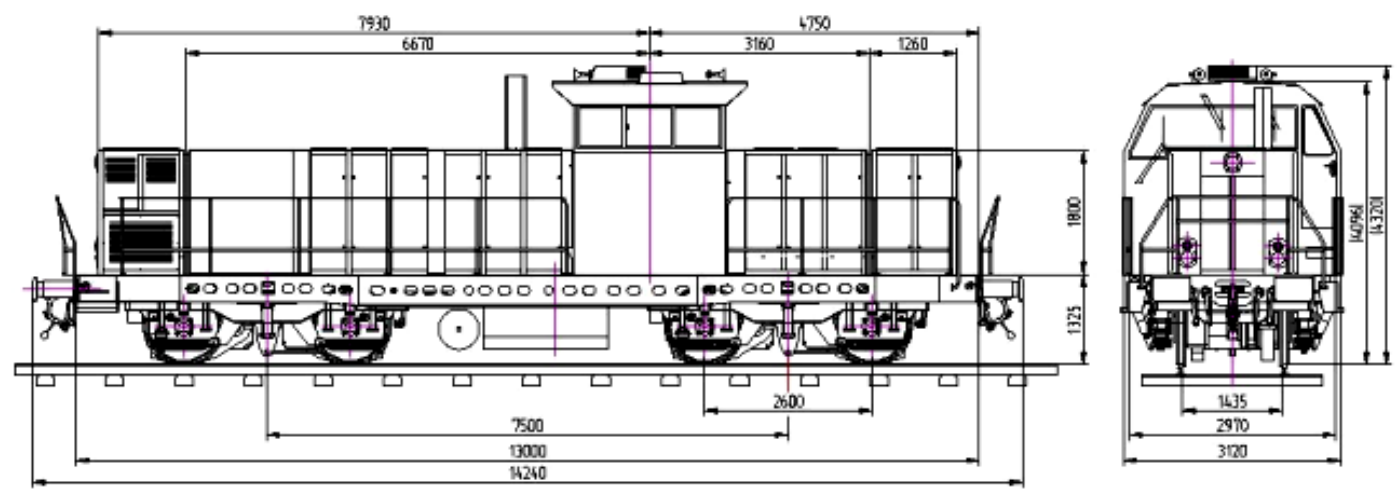

Rys.3 Widok ogólny lokomotywy wraz z wymiarami zmodernizowanej lokomotywy typu 6Di z silnikiem MAN 
Rys.4 Charakterystyki trakcyjne zmodernizowanej lokomotywy typu 6Di z silnikiem MAN (adla pociagu o masie 400 $\mathrm{t}$, b-dla pociagu o masie $2000 \mathrm{t}$ )
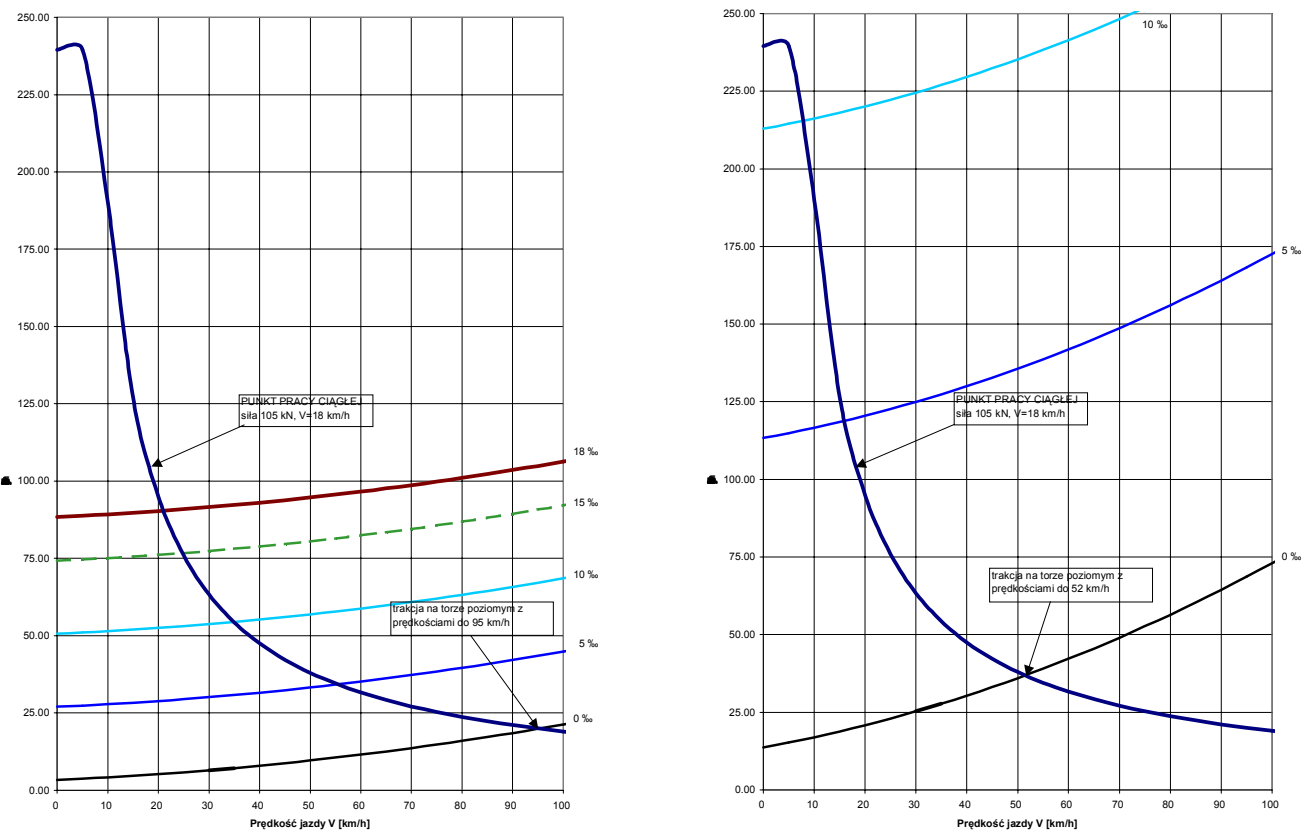

Rys.5 Widok ogólny rozmieszczenia maszyn i urządzeń w zmodernizowanej lokomotywie typu $6 \mathrm{Di}$

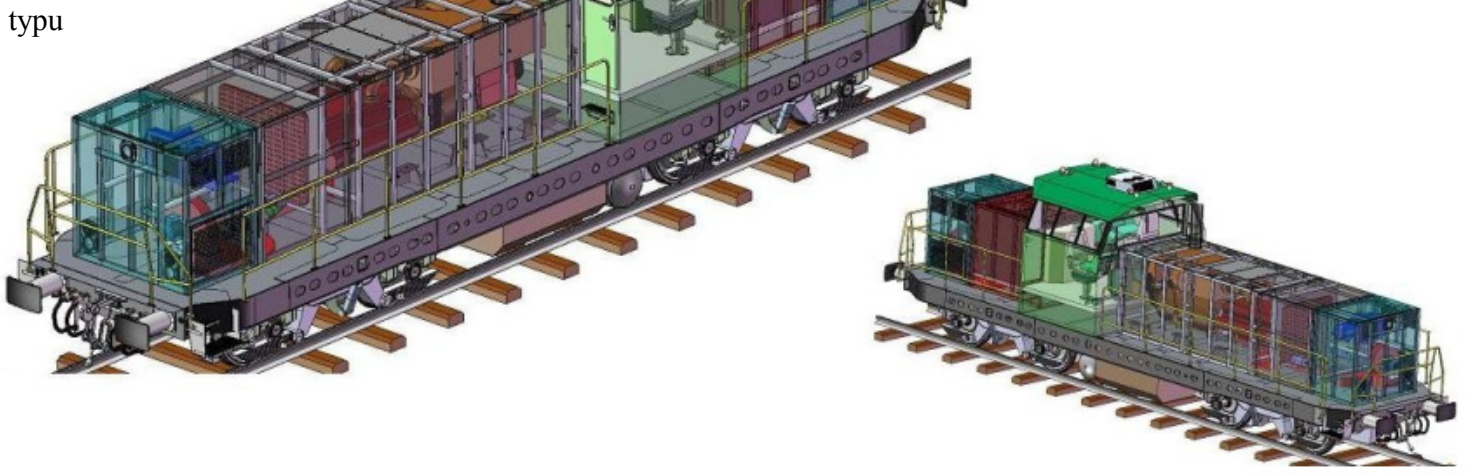

Rys.6 Ogólne zestawienie głównych modułów w zmodernizowanej lokomotywie typu 6Di

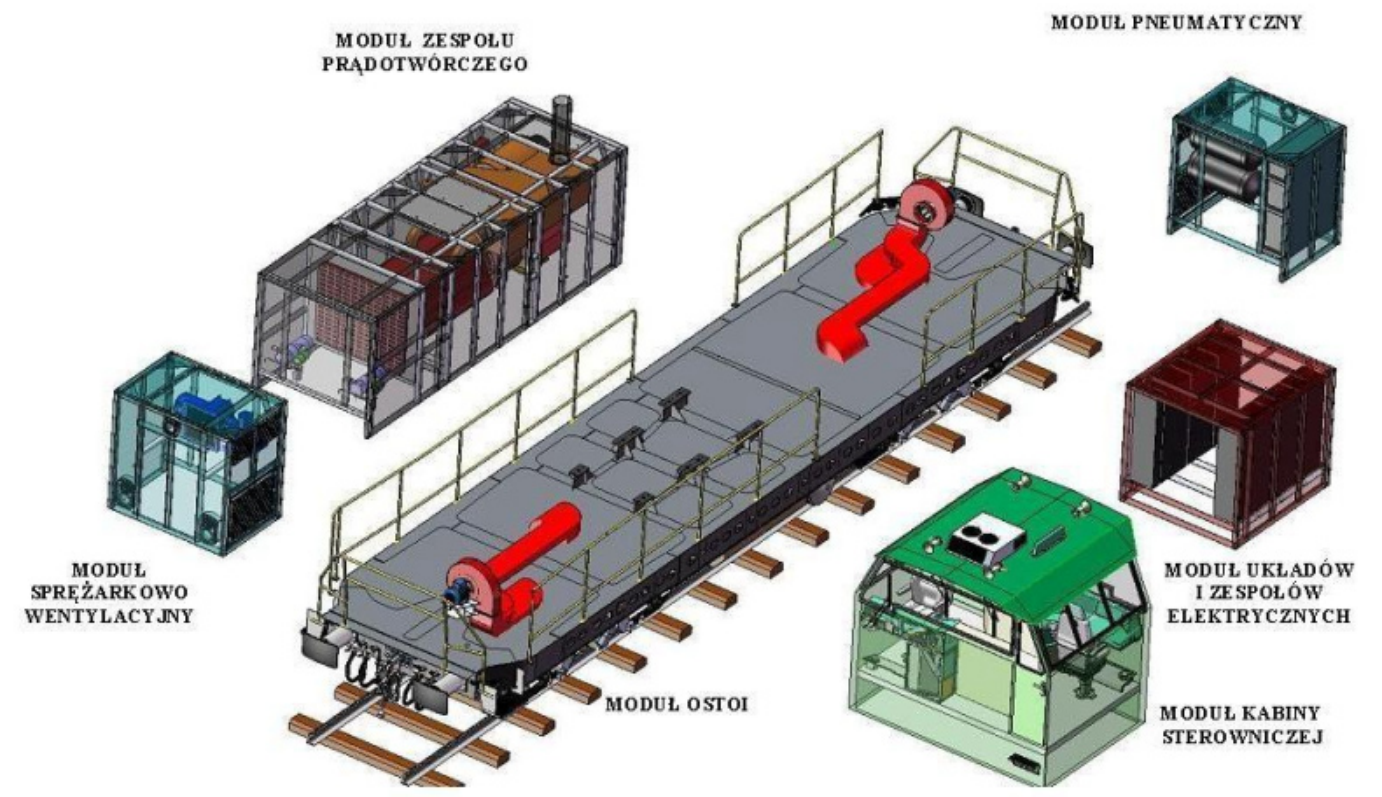


W modernizowanej lokomotywie zachowana zostanie ostoja (przystosowana do mocowania nowych modułów, kanałów kablowych oraz o zwiększonej wytrzymałości) oraz wózki typu 1LN (lub 1LNa) ze zbiornikami piasku. Cała ostoja zostanie wzmocniona płytą o grubości $20 \mathrm{~mm}$.

Pozostałe zmodernizowane i nowe urządzenia, aparaty, maszyny i układy to $[1,4]$ :

- silnik spalinowy typu D2842LE622 o mocy $662 \mathrm{~kW}$, spełniający wymagania toksyczności spalin poziom IIIa o minimalnym zużyciu paliwa $202 \mathrm{~g} / \mathrm{kWh}$

- zespół prądnic - główna Ghp 400M4C o mocy $590 \mathrm{~kW}$, z zabudowaną wzbudnicą i pomocnicza Ghp 315S4K o mocy 63kW

- tablica pneumatyczna

- agregat sprężarkowy ze sprężarką śrubowa napędzaną silnikiem prądu przemiennego

- kabina sterownicza z dwoma niezależnymi pulpitami i fotelami, o wysokiej izolacji cieplnej i akustycznej, szybami ogrzewanymi elektrycznie, lusterkami zewnętrznymi lub kamerami, szafami sterowniczymi, szafami z generatorami SHP i CA oraz centralką p-poż. Kabina została posadowiona na amortyzatorach gumowo-metalowych, a dach kabiny przystosowany do zabudowy wentylatora wyciagowego lub schładzacza

- układ sterowania i diagnostyki (mikroprocesorowy)

- układ przeciwpoślizgowy przy rozruchu i hamowaniu

- urządzenia związane z bezpieczeństwem ruchu oraz łączności radiowej

- elektroniczne prędkościomierze i rejestratory głównych parametrów pracy lokomotywy

- halogenowe oświetlenie zewnętrzne i lampy sygnałowe

a)

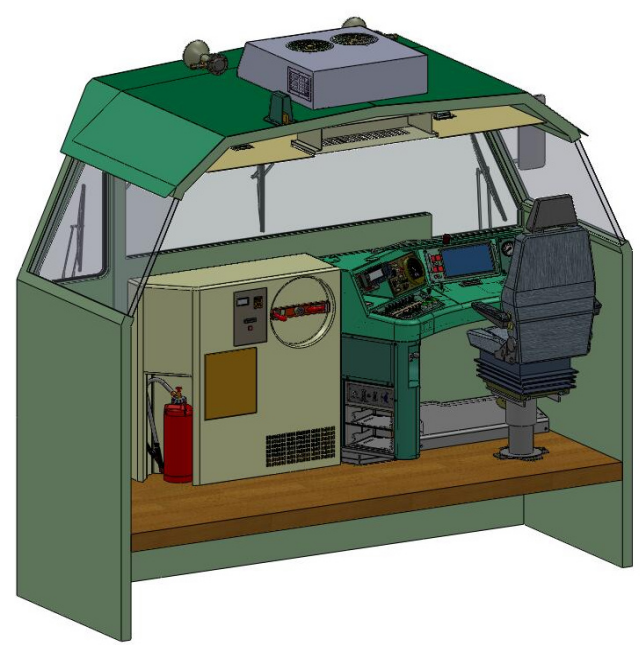

b)

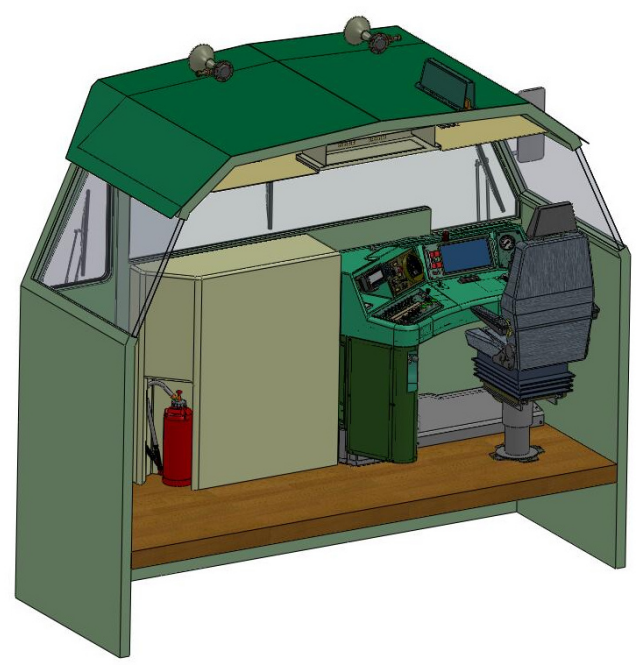

Rys.7 Moduł zmodernizowanej kabiny sterowniczej z zabudowanym schładzaczem a-widok na stronę modułu prądotwórczego, b-widok na stronę modułu elektrycznego

Lokomotywa jest przystosowana do zabudowy innych typów silników spalinowych (spełniających również wymagania poziomu IIIb) oraz innego wyposażenia zgodnego $\mathrm{z}$ wymaganiami każdego użytkownika.

Widok ogólny na wybrane zmodernizowane moduły przedstawiono na rys.7-10 a schemat blokowy układu elektrycznego na rys.11.

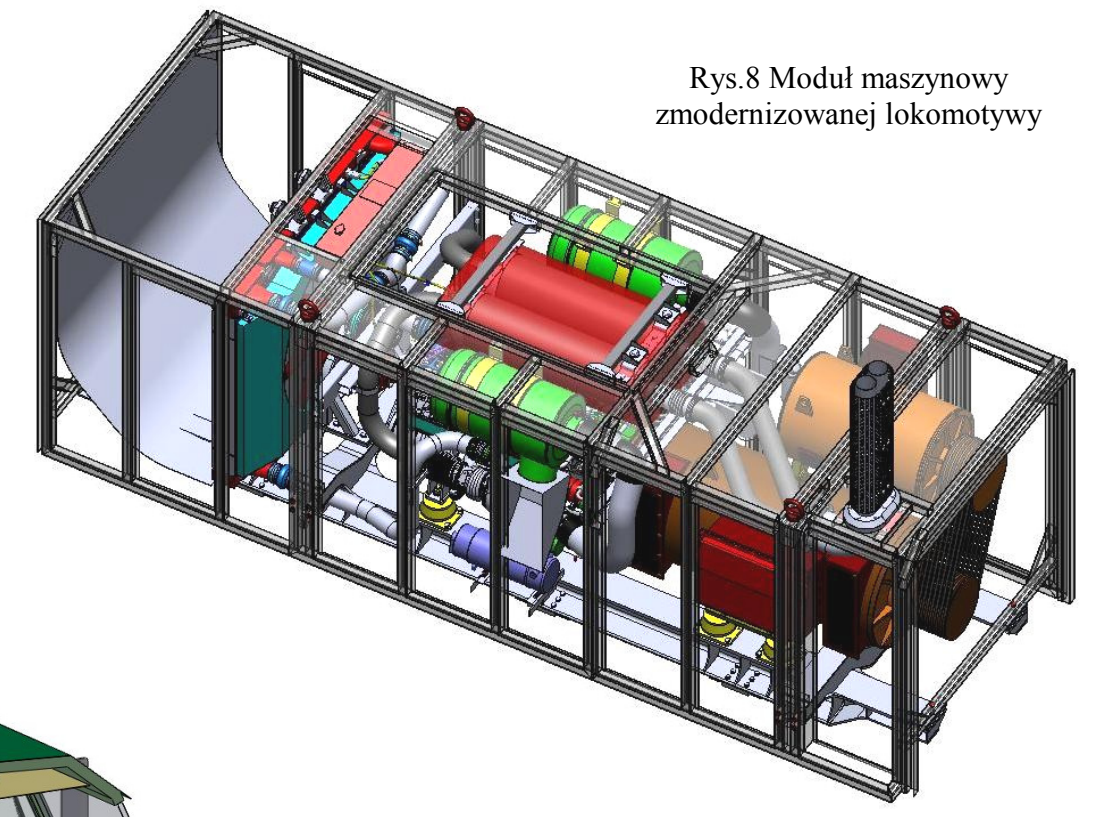

\section{Podsumowanie}

Odbudowana lokomotywa po wykonaniu modernizacji zostanie skierowana do prób i badań zgodnie $\mathrm{z}$ obowiązującym jeszcze zakresem wymienionym $\mathrm{w}$ Rozporządzeniu Ministra Infrastruktury $\mathrm{z}$ dnia 12.10.2005r. (Dz. U. nr 212 poz. $1772 \S 4$ pkt 1).

Zakres prób i badań obejmować będzie:

- odbiory zgodnie $\mathrm{z}$ wymaganiami ujętymi w Warunkach Technicznych Odbioru

- analizy dynamiczne, wytrzymałościowe i kinematyczne 

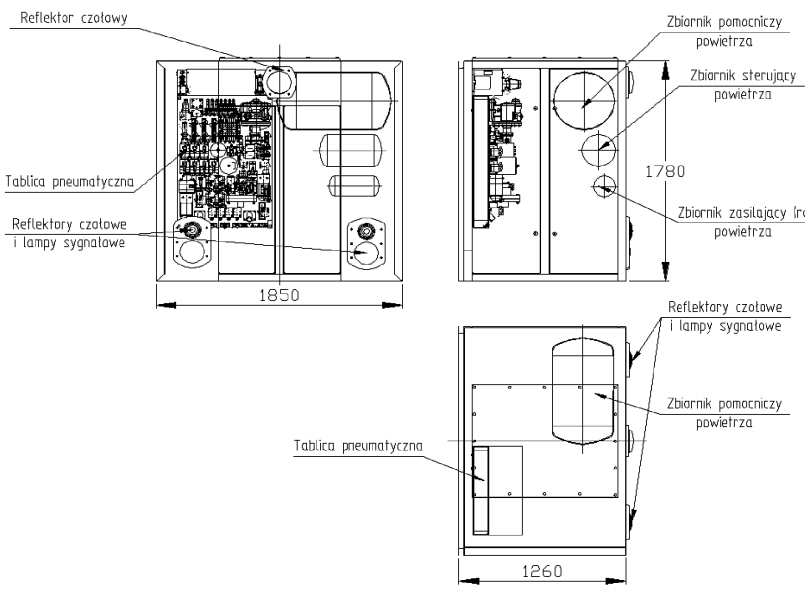

Rys.9 Widok ogólny modułu pneumatycznego

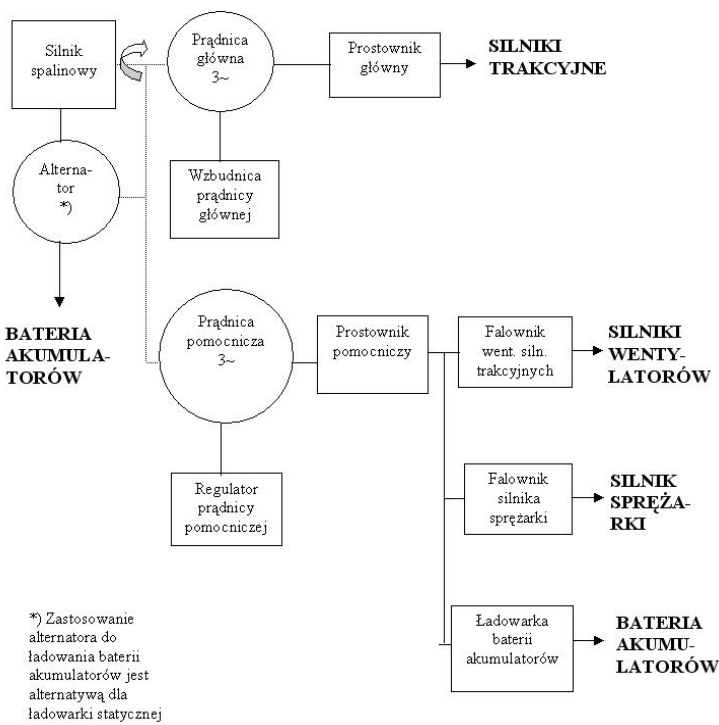

Rys.11 Schemat układu elektrycznego zmodernizowanej lokomotywy

- określenie rzeczywistych charakterystyk trakcyjnych

- badanie układów hamulca, urządzeń przeciwpoślizgowych oraz urządzeń związanych $\mathrm{z}$ bezpieczeństwem ruchu i rejestracją parametrów pracy lokomotywy

- badanie hałasu zewnętrznego oraz oświetlenia i sygnalizacji (świetlnej i akustycznej)

- badanie wpływu lokomotywy na pracę urządzeń sterowania ruchem kolejowym i sygnalizacji

- ocena zakłóceń radioelektrycznych i elektromagnetycznych (wewnętrznych i zewnętrznych)

- ocena warunków pracy maszynistów (hałas, oświetlenie wewnętrzne, ergonomia, ogrzewanie, schładzanie, indukcyjność pola magnetycznego)

- 6-miesięczne próby eksploatacyjne po uzyskaniu terminowego świadectwa dopuszczenia do eksploatacji pojazdu kolejowego.

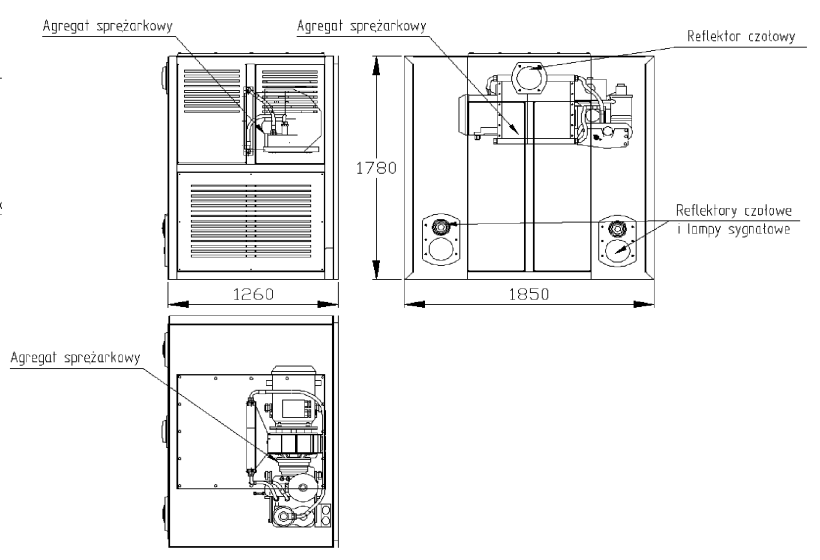

Rys.10 Widok ogólny modułu sprężarkowego

Największe korzyści z modernizacji zostaną osiągnięte po wdrożeniu do eksploatacji większej liczby zmodernizowanych lokomotyw. Ponadto ciekawym byłoby porównanie eksploatacyjne wszystkich zmodernizowanych lokomotyw typu 6Dg, 6Di, 6Dk (serii SM42) w porównywalnych warunkach pracy. Z analizy rynku spalinowych lokomotyw eksploatowanych $\mathrm{w}$ Polsce do modernizacji nadawałyby się jeszcze lokomotywy serii SM30, SM31 i typu 401Da, których ilość przyniosłaby oczekiwane efekty ekonomiczne.

\section{Literatura.}

[1] Marciniak Z. + zespót; Zatożenia do projektu technicznego zmodernizowanej spalinowej lokomotywy serii SM42. Opracowanie 6Di (SM42) 0005-2, IPS TABOR Poznań, 2009

[2] Marciniak Z.; Projekty modernizacyjne spalinowych lokomotyw liniowych $i$ manewrowych wykonanych $w$ Instytucie Pojazdów Szynowych, Logistyka, 2010, nr 4.

[3] Marciniak Z.; Zmodernizowane $w$ ostatnich latach lokomotywy elektryczne i spalinowe w Polsce. Technika Transportu Szynowego, 2011, nr 4.

[4] Dokumentacja konstrukcyjna zmodernizowanej lokomotywy spalinowej typu 6Di. Opracowanie IPS TABOR Poznań, 2010/2011 